\title{
FMRFamide Peptides in Helisoma: Identification and Physiological Actions at a Peripheral Synapse
}

\author{
A. G. M. Bulloch, D. A. Price, ${ }^{1}$ A. D. Murphy, ${ }^{2}$ T. D. Lee, ${ }^{3}$ and H. N. Bowes \\ Neuroscience Research Group and Department of Medical Physiology, University of Calgary, Health Sciences Center \\ Calgary, Alberta T2N 4N1, Canada, ${ }^{1}$ C. V. Whitney Laboratory, University of Florida, St. Augustine, Florida 32086, \\ ${ }^{2}$ Department of Biological Sciences, University of Illinois at Chicago, Chicago, Illinois 60680, and ${ }^{3}$ Division of Immunology, \\ Beckman Research Institute, City of Hope, Duarte, California 91010
}

Previous reports have demonstrated powerful neuromodulatory actions of the molluscan tetrapeptide FMRFamide in both the central and peripheral nervous systems of the freshwater snail Helisoma. The present study was designed to examine both the nature of the FMRFamide-like peptides in Helisoma and to define their physiological actions at a peripheral synapse. We report that, as determined by HPLC/ RIA and mass spectrometry, Helisoma contains both FMRFamide and 2 of its analogs, FLRFamide and GDPFLRFamide. Whereas whole animals contain about 100 $\mathrm{pmol} / \mathrm{gm}$ of these peptides, they were enriched in the nervous system (3000 $\mathrm{pmol} / \mathrm{gm})$ and in a peripheral target organ, the salivary glands (500 $\mathrm{pmol} / \mathrm{gm})$.

For histochemical and physiological studies we examined the salivary glands, which are known to be innervated by neuron 4 of the buccal ganglion. We confirmed the presence of FMRFamide-like fibers on the salivary gland by immunohistochemistry using a polyclonal antiserum. These fibers appear to be largely derived from somata located in the central ring ganglia. For physiological tests we examined the neuron 4-gland synapse, at which presynaptic action potentials normally evoke a suprathreshold EPSP in gland cells. Bath application of FMRFamide, FLRFamide, or GDPFLRFamide at micromolar concentration to a buccal ganglia/salivary gland preparation completely suppressed spontaneous rhythmic activity. The sites of action of these peptides were examined by iontophoretic application of FMRFamide to neuron 4 or the salivary gland. Application of the peptide to the soma of neuron 4 caused a hyperpolarization that suppressed spontaneously generated action potentials. When applied to the salivary gland, FMRFamide caused a hyperpolarization that reduced the EPSPs evoked by neuron 4 to below spike threshold. The latter observation implies a postsynaptic locus of action for FMRFamide, and this possibility was tested by direct depolarization of the gland with iontophoresis of ACh (the putative transmitter of neuron 4). Such depolarizations were also reduced by FMRFamide.

Received Sept. 30, 1987; revised Dec. 14, 1987; accepted Dec. 25, 1987

We thank J. Bishop for supplying the FMRFamide antibody and the recipe for the FMRFamide-thyroglobulin conjugate; J. P Riehm for the synthesis of GDPFLRFamide; M. Greenberg and K. Lukowiak for their support; and D. Hunt for preparation of the manuscript.

Correspondence should be addressed to A. G. M. Bulloch at the above address. Copyright (C) 1988 Society for Neuroscience $0270-6474 / 88 / 093459-11 \$ 02.00 / 0$
We conclude that Helisoma contains FMRFamide and 2 of its analogs, these peptides being enriched in the nervous system and salivary glands. Furthermore, these peptides can suppress activation of the salivary glands by actions both directly on gland cells and on the effector neuron.

The large number of conventional transmitters and neuroactive peptides, and the coexistence of 2 or more transmitters in the same neuron, are 2 little understood features of the nervous system. The coexistence of peptides with conventional transmitters has caused speculation that peptides may have a range of other actions. Functions already attributed to peptides in the nervous system include vasodilation (Edvinsson, 1985), transneuronal regulation of enzymes (Ip et al., 1982), trophic effects (Nilsson et al., 1985; Bulloch, 1987), and neuromodulatory actions (Iverson, 1984). Although peptides appear to act as primary transmitters in a few instances (e.g., Otsuka et al., 1982), neuromodulatory roles appear to be more common (e.g., Bloom, 1983; North and Williams, 1983; Mudge et al., 1979). Sites of action of peptides include both the presynaptic terminal, and postsynaptic sites such as receptors, voltage-sensitive channels, receptor-activated channels, and the input impedance (Pittman, 1980).

Any attempt to understand the role of peptides in a given system must approach at least 2 critical questions: First, what endogenous peptides does the system contain, and, second, what are their pre- and/or postsynaptic actions? The molluscan nervous system has provided some unique opportunities in this context. For example, the peptide $\mathrm{SCP}_{\mathrm{B}}$ was first extracted and sequenced from Aplysia ganglia (Morris et al., 1982), and subsequently its action on muscle via a second messenger system has been elucidated (Lloyd et al., 1984). A number of laboratories have recorded evidence for as broad a range of neuroactive peptides in molluscs as exists in vertebrates. In fact, the common gut-brain distribution of peptides such as somatostatin and FMRFamide observed in molluscs (e.g., Bulloch, 1987) is reminiscent of that observed in higher animals (reviewed by Said, 1980; Grimm-Jorgensen, 1986).

The neuronal circuitry responsible for generating feeding behavior in molluses has bcen studicd in a varicty of species (reviewed by Benjamin et al., 1985; Getting, 1985). In the case of Helisoma, a number of motoneurons, other effector neurons, and interneurons responsible for generating the rhythmic patterned motor activity (PMA) associated with feeding have been identified (Kater and Rowell, 1973; Kater, 1974; Kaneko et al., 1978; Kater et al., 1978). More recent work has begun to con- 
sider the modulation of PMA and peripheral synaptic efficacy by peptides, monamines, and amino acids (Granzow and Kater, 1977; Trimble and Barker, 1984; Coates and Bulloch, 1985; Murphy et al., 1985; Jones et al., 1987; Murphy and Lukowiak, 1987). From these studies it is clear that modulation of the circuitry that underlies feeding can occur at both the level of interneurons and effector neurons. To date, however, studies involving peptides have not included a rigorous examination of the endogenous peptides contained in the Helisoma nervous system.

In a previous study we showed that the neuroglandular synapse of Helisoma exhibits physiological plasticity which can be exploited by peptides such as FMRFamide and $\mathrm{SCP}_{\mathrm{B}}$ (Coates and Bulloch, 1985). Specifically, we examined the subthreshold modulation of EPSPs (using high-magnesium, low-calcium salines) evoked by stimulation of the effector neuron to the salivary gland, buccal neuron 4. Bath application of FMRFamide reduced EPSP amplitude, partly by hyperpolarization of neuron 4 and partly by decreased input impedance of gland cells. Additionally, it is known that FMRFamide can suppress the PMA expressed by some of the feeding effector neurons of Helisoma (Murphy et al., 1985). The present study was designed to answer 2 questions: First, what is the nature of endogenous FMRFamide-like peptides in Helisoma, and, sccond, can applications of such peptides modulate activation of the salivary gland during PMA?

\section{Materials and Methods}

These studies using specimens of albino ("red") Helisoma snails obtained from inbred laboratory cultures that were maintained as described previously (Jones et al., 1987).

\section{Peptide analysis}

Preparation of acetone extracts. The FMRFamide-like peptides from whole snails ( $n=75$ ), dissected central ring ganglia ( 2 batches, $n=100$ and 500), and dissected salivary glands $(n=50)$ were extracted with acetone. For the dissection method, see Kater and Kaneko (1972). Whole animals were crushed in a graduated cylinder to give $50 \mathrm{ml}$ compact volume (original was $80-100 \mathrm{ml})$. Acetone $(200 \mathrm{ml})$ was added and the contents well mixed. The mixture was kept in the freezer for a few days before some of the supernatant acetone $(15 \mathrm{ml})$ was removed for pilot studies.

Treatment of acetone extracts for HPLC. In all cases the acetone was centrifuged (Sorvall, 5-10 min, 10,000 rpm, whole animal extracts, or Beckman Microfuge B, 2 min, others) and the supernatant reduced in volume with a rotary evaporator heated to $50-55^{\circ} \mathrm{C}$ under water aspirator vacuum (it is important to remove all of the acetone before HPLC). For the dissected ganglia this liquid was injected directly onto the HPLC. For both the whole animals and the salivary glands an equal volume of $0.1 \%$ trifluoroacetic acid (TFA) in water was added to the residual fluid (about $10 \%$ of original volume). The liquid was well mixed and centrifuged as above. The supernatants were forced through a syringe filter $(0.2 \mu \mathrm{m})$ and applied to the HPLC column either through the injector (Waters $\mathrm{U} 6 \mathrm{~K}$ ) or through the pump intake depending on the volume.

First HPLC step. All of the extracts were run first on a $\mathrm{C} 18$ reversephase HPLC column with a TFA/acetonitrile (ACN) solvent system. Some slight differences in the gradients and columns used are noted in the figure legends. When the sample was pumped onto the HPLC column through the aqueous solvent pump, it was washed in with additional aqueous solvent $(0.1 \%$ TFA) until the UV absorbance had dropped to about $90 \%$ of its original level. Then, the flow was switched to the usual initial conditions $(80 \%$ aqueous $0.1 \%$ TFA $20 \% 0.1 \%$ TFA in $80 \%$ $\mathrm{ACN}$ ). When the front of this solvent reached the detector (as evidenced by a rapid increase in the UV absorbance), a linear gradient to $60 \%$ aqueous $/ 40 \%$ organic over 20 min was started. (Thus, the ACN concentration ranges from 16 to $32 \%$.) This same gradient is used with the injector, so the elution times of peptides are very similar. The flow rate was $2 \mathrm{ml} / \mathrm{min}$, and $1 / 2 \mathrm{~min}$ fractions $(1 \mathrm{ml})$ were collected. The UV absorbance was monitored at $210 \mathrm{~nm}$. Aliquots, $2 \mu \mathrm{l}$, were taken from each fraction for radioimmunoassay (RIA) as previously described (Price et al., 1987) and were used to compute the peptide in each fraction.

Further HPLC purification. The peak fractions from the whole-animal extracts were injected directly into the next HPLC system (i.e., they were not dried or even reduced in volume). Often aqueous solvent or water was added to the fraction before injection, but this was not absolutely necessary. Only 1 or 2 combined fractions from each peak were reinjected. The second HPLC system also contains $0.1 \%$ TFA, but $n$-butanol was the organic solvent. The weaker solvent was $2 \%$ (by volume) butanol, and the stronger one was $8 \%$ (which is about the saturating level of $n$-butanol in $0.1 \%$ aqueous TFA), and the gradient was from $100 \%$ of $2 \%$ to $100 \%$ of $8 \%$ in $20 \mathrm{~min}$. The flow rate was again $2 \mathrm{ml} /$ $\mathrm{min}$, and $1 / 2 \mathrm{~min}$ fractions were collected. A Waters NovaPak C-18 stainless steel column was used for all of these solvent runs. The wholeanimal extracts could be resolved into pure component peptides by alternating use of these 2 solvent systems.

After the first HPLC run on a TFA/ACN system using a Microbondapak $\mathrm{C} 18$ column, the fractions comprising the heptapeptide peak from the second ganglionic extract were combined and lyophilized. The residue was dissolved in $3 \mathrm{~mm}$ sodium caprylate and injected onto a Novapak C1 8 column eluted with a gradient of ACN (10-25\%) in $3 \mathrm{~mm}$ sodium caprylate (pH 7.0) over $20 \mathrm{~min}$. The flow rate was $2 \mathrm{ml} / \mathrm{min}$, and $1 / 2$ min fractions were collected and aliquots taken for RIA.

\section{Mass spectrometry}

Positive-ion fast atom bombardment (FAB) mass spectra (Lee, 1986) were obtained using a JEOL HX $100 \mathrm{HF}$ high-resolution, double-focusing, magnetic sector mass spectrometer operating at $5 \mathrm{kV}$ accelerating potential and a nominal resolution of 3000 . Sample ionization was accomplished using a $6 \mathrm{keV}$ Xe atom beam. Samples for mass spectral analysis were submitted dry in $1.5 \mathrm{ml}$ polypropylene tubes and were dissolved in a few microliters of 5\% aqueous acetic acid. A 1-2 $\mu 1$ of the sample solution was added to approximately $1 \mu \mathrm{l}$ of liquid matrix on a $1.5 \times 6.0 \mathrm{~mm}$ stainless steel sample stage on the end of a direct insertion probe. The liquid matrix consists of dithiothreitol:dithioerythritol $(5: 1), 6 \mathrm{~mm}$, in camphor sulfonic acid. Solvent was removed from the sample in the inlet vacuum lock of the mass spectrometer.

Spectral data were acquired and stored using a JEOL DA5000 data system in 1 of 2 ways, i.e., normal magnetic sector scans and $B / E$ linked scans. For normal spectra, the electric sector of the mass spectrometer is set to transmit all ions at source potential $(5 \mathrm{kV})$, and the magnetic field is scanned over a given mass range. In most instances, the mass range scanned was $200-2000 \mathrm{~m} / \mathrm{z}$, with a cycle time of approximately $30 \mathrm{sec}$. For B/E scans (Mclafferty, 1983), the electric sector voltage is linked to the magnetic sector field strength such that the ratio is constant. The resulting spectrum includes only those ions that result from metastable decompositions of a selected precursor mass; in these instances, the protonated molecular ion. It is possible with one sample loading to acquire a normal spectrum along with one or more $B / E$ spectra. The $\mathrm{B} / \mathrm{E}$ scans of protonated molecular ions of peptides provide a means of obtaining sequence-related fragment ions which would be otherwise obscured by ions derived from the matrix and sample impurities. Studies with synthetic standard peptides indicate that $\mathrm{B} / \mathrm{E}$ linked scan spectra provide useful sequence information with sample amounts as low as $100-200 \mathrm{pmol}$. Sample amount for spectra obtained in this study ranged from 200 to 800 pmol, based on RIA results.

\section{Immunohistochemistry}

FMRFamide-like peptides were localized in the salivary glands and nervous system with conventional indirect immunofluorescent methods. This study employed whole mounts of ganglia from $3-4 \mathrm{~mm}$ vertical shell diameter snails, and $10 \mu \mathrm{m}$ paraffin sections from $10-12 \mathrm{~mm}$ snails, which were treated as described previously (Murphy et al., 1985; Bulloch, 1987), except that no colchicine pretreatment was employed. We used a rabbit polyclonal antiserum to FMRFamide (dilution 1:200) provided by J. Bishop (O'Donohue et al., 1984; Chronwall et al., 1984), as used on Helisoma previously (Murphy et al., 1985). Fluorescein goat anti-rabbit IgG (dilution 1:20) was obtained from Sigma. Preabsorption controls used the primary antiserum preabsorbed overnight at $4^{\circ} \mathrm{C}$ with either synthetic peptide at $0.1 \mathrm{~mm}$, a FMRFamide-thyroglobulin conjugate at $0.1 \mathrm{mg} / \mathrm{ml}$, thyroglobulin at $0.1 \mathrm{mg} / \mathrm{ml}$, or a GABA-BSA conjugate at $0.1 \mathrm{mg} / \mathrm{ml}$. The FMRFamide conjugate was tested since the 
FMRFamide antibody was originally generated against this molecule, and we used the original recipe for the conjugation that was provided by J. Bishop. Preparations were viewed by epifluorescence using a Zeiss Universal microscope equipped with a bandpass excitation filter (485/ $20 \mathrm{~nm}$ ), a $520 \mathrm{~nm}$ barrier filter, a $510 \mathrm{~nm}$ dichroic mirror, and a 100 W DC mercury arc lamp. Low-power photomicrographs employed Neofluar objectives $(6.3$ and $10 \times)$, whereas high-power shots were via a Plan-Neofluar $25 \times$ immersion objective having both a long enough working distance $(0.32 \mathrm{~mm})$ for use with whole mounts and a high numerical aperture $(0.8)$.

\section{Electrophysiology}

Standard electrophysiological techniques were applied to preparations consisting of the salivary glands and attached buccal ganglia (Bahls et al., 1979) or the isolated salivary gland. Preparations were pinned to the base (RTV 616 silicone rubber, GE) of a $1 \mathrm{ml}$ chamber of continuously perfused with saline at $3 \mathrm{ml} / \mathrm{min}$. Intracellular glass microclectrodes contained $0.75 \mathrm{M} \mathrm{KCl}$ (resistance, 20-30 M ), signals being recorded by a Neurodata amplifier using bridge-balance as described previously (Bulloch, 1987). Signals were stored on a VCR tape deck (Vetter $420 \mathrm{~B}$ ) and displayed on a Gould $2200 \mathrm{~S}$ pen recorder and a Nicolet 4094 digital oscilloscope. All records in the text are from the pen recorder, except Figure 9, $B, C$, which was plotted from the Nicolet by a HP7470A plotter. For iontophoresis we employed a Neurophore $\overline{\mathrm{B}} \overline{\mathrm{H}}-\overline{2}$ iontophoresis main frame (Medical System Corp.). The tip of the current barrel of the double-barreled iontophoretic electrodes was filled with 2-5 $\mu$ l of $5 \mathrm{~mm}$ FMRFamide in distilled water, the remainder of the barrel being filled with normal saline (resistance, $30-100 \mathrm{M} \Omega$ ); the other barrel contained $3 \mathrm{M} \mathrm{NaCl}$, this being used for current balance. FMRFamide was ejected with positive currents of 10-150 nA, no backing current usually being required. For iontophoresis of $\mathrm{ACh}$, a $0.2 \mathrm{M}$ solution of acetylcholine chloride (Sigma) in distilled water was utilized in a single-barreled electrode, this being ejected by low positive currents (5-20 nA), with backing currents of $1-10 \mathrm{nA}$ as required.

The compositions of normal Helisoma physiological saline and high$\mathrm{Mg}^{2+}(18.9 \mathrm{~mm})$, low- $\mathrm{Ca}^{2+}(0.1 \mathrm{~mm})$ saline were as described previously (Jones et al., 1987). The peptides FMRFamide and FLRFamide were obtained from Bachem and Sigma, respectively, GDPFLRFamide being synthesized by J. P. Riehm of the University of West Florida. All peptides were made up fresh before each experiment from frozen aliquots stored at millimolar concentration at $-20^{\circ} \mathrm{C}$.

\section{Data Analysis}

Data are expressed as means \pm SEM, tests for significance between sample groups being by the 2-tailed Student's $t$ test using a correction for unmatched variance (Dixon and Massey, 1969). The level of significance taken was $P<0.05$; if data groups were significantly different, the $P$ value is indicated on the graph; otherwise, no value is indicated (Fig. 6). Graph lines were fitted using linear-regression analysis (Fig. 6).

\section{Results}

This study progressed in 3 stages. First, we combined HPLC, RIA, and mass spectrometry to analyze the nature of the FMRFamide-like peptide in whole animals, ganglia, and salivary glands of Helisoma. Second, we examined the salivary gland for the presence of FMRFamide-like fibers by immunohistochemistry. Finally we examined modulation of the neuron 4gland synapse, initially by bath application of FMRFamide peptides, and subsequently by local application of FMRFamide with iontophoresis.

\section{Analysis of FMRFamide-like peptides}

All acctone extracts were light yellow in color, but much of the yellow pigment was not water soluble and fell from solution during rotary evaporation. More pigment precipitated when the $0.1 \%$ TFA was added, but it tended to stay in suspension, giving a cloudy solution. The syringe filter removed the cloudiness and yielded a filtrate that was not turbid and only faintly yellow or even water white. All extracts gave similar patterns of immu- noreactivity in the TFA/ACN HPLC system. Whereas whole animals contained a total of about $100 \mathrm{pmol} / \mathrm{gm}$ of immunorcactive peptides, the levels were enriched in both the ring ganglia (3000 pmol/gm) and the salivary glands (500 pmol/gm).

Whole animals. Four separate portions of the whole-animal extract were run: 2 pilot runs with 5 and $10 \mathrm{ml}$ of the supernatant acetone and 2 major runs of 125 and about $100 \mathrm{ml}$ of acetone. A typical elution pattern is shown in Figure $1 A$; the patterns did vary somewhat depending on the amount of material applied. Examples of purified samples from which peak fractions were taken for mass spectrometry are shown in Figure $1 B$.

Mass spectral analysis of the immunoreactive peaks was used to confirm structural assignments based on HPLC retention times. Spectra (Fig. 2) for the sample corresponding to FMRFamide (fraction 15, Fig. $1 A$ ) are typical and serve to illustrate the technique. In the normal (magnetic field scan) FAB spectrum (Fig. $2 A$ ), a prominent ion was observed at $\mathrm{m} / z$ 599.25, which corresponded to the protonated molecular ion $(\mathrm{MH}+)$ of FMRFamide (calculatcd valuc, 599.31). The B/E linked scan spectrum (Fig. $2 B$ ) of the protonated molecular ion $(m / z 599)$ in the normal FAB spectrum contains sufficient information to define the sequence of the peptide.

The peak at the elution position of standard FLRFamide (fraction 18, Fig. 1 $A$ ) was somewhat more prominent in other runs (not shown). Mass spectral analysis of the isolated HPLC peak yielded a prominent protonated molecular ion at $\mathrm{m} / \mathrm{z} 581.41$ (calculated value, 581.35). The B/E linked scan spectrum contained sufficient information to confirm the sequence.

The largest peak in the chromatogram (fraction 26, Fig. $1 A$ ) eluted at the same time as a number of heptapeptide standards (specifically GDPFLRFamide, SDPFLRFamide, and NDPFLRFamide). Although it is possible to resolve these peptides by carefully controlling HPLC conditions, in this instance it proved unnecessary. FAB mass spectral analysis of the isolated peak revealed only the protonated molecular ion corresponding to GDPFLRFamide (observed value, 850.49 ; calculated value, 850.44 ). Although the number of sequence-related fragments in the B/E linked scan spectrum was not sufficient to totally define the sequence, enough were present to leave little doubt about the structural assignment. One fragment is particularly diagnostic for all heptapeptide species that contain the DPFLRFamide portion of the sequence. Specifically, cleavage of the amide bond between the Asp and Pro residues always gives an intense C-terminal fragment at $\mathrm{m} / z 678$ in the linked scan spectra of these peptides.

The minor peak at fraction 8 (Fig. $1 A$ ) corresponds in elution time to oxidized FMRFamide and was not studied further. Other minor peaks of immunoreactivity were seen in some runs, but not in others, and were not further purified.

Ganglia. All of the peaks seen in the whole-animal extract appear to be present in the HPLC patterns of ganglia (e.g., Fig. $3 \mathrm{~A}$ ), although the pattern is not as clear as that for whole animals (cf. Fig. 1A). The heptapeptide peak (fractions 24, 25, and 26) was rürtier purified on an FPLC system that could resolve GDPFLRFamide and SDPFLRFamide; only GDPFLRFamide was observed (Fig. 3B).

Salivary Glands. Only a small number of salivary glands were extracted, so it was necessary to dry down the HPLC fractions and analyze a large proportion of the fraction by RIA. A heptapeptide, presumably GDPFLRFamide, was present as well as the smaller amount of FMRFamide. No FLRFamide could be detected at this level. 
Figure 1. HPLC/RIA separation of FMRF-amide peptides from whole animals. A, Profile of the FMRFamiderelated immunoreactivity in an acetone extract of snails fractionated by HPLC. The extract was loaded onto a $\mathrm{C} 18 \mathrm{col}-$ umn (stainless steel NovaPak C18 column, $3.9 \times 15 \mathrm{~cm}$ ) through the pump intake, the column was washed with $0.1 \%$ aqueous TFA, and then very briefly (1-2 min) with $16 \%$ ACN containing $0.1 \%$ TFA. At this point (fraction 0), a gradient to $32 \% \mathrm{ACN}, 0.1 \%$ TFA over $20 \mathrm{~min}$ was started, and $0.5 \mathrm{~min}$ fractions were collected. (A fiow rate of 2 $\mathrm{ml} / \mathrm{min}$ was maintained throughout.) After the run, an aliquot was taken from each fraction for radioimmunoassay, and the total amount of FMRFamidelike immunoreactivity in each fraction was computed. A mixture of standards was injected under the same gradient conditions immediately after the extract and their elution times are marked on the profile. $B$, As the final step in their purification the peaks corresponding to FMRFamide, FLRFamide, and GDPFLRFamide were run again under the same conditions as shown in $A$. The UV profile of each run and its immunoreactivity profile are shown. The UV traces were recorded at 0.1 AUJFS for the outer two (FMRFamide and GDPFLRFamide) and at 0.04 AUFS for the middle one (FLRFamide). Standards were run, and they eluted very close to the times shown in $A$ (FMRFamide, 7.20; FLRFamide, 8.67; GDPFLRFamide, 12.95). The peak fraction from each run was used for mass spectroscopy.
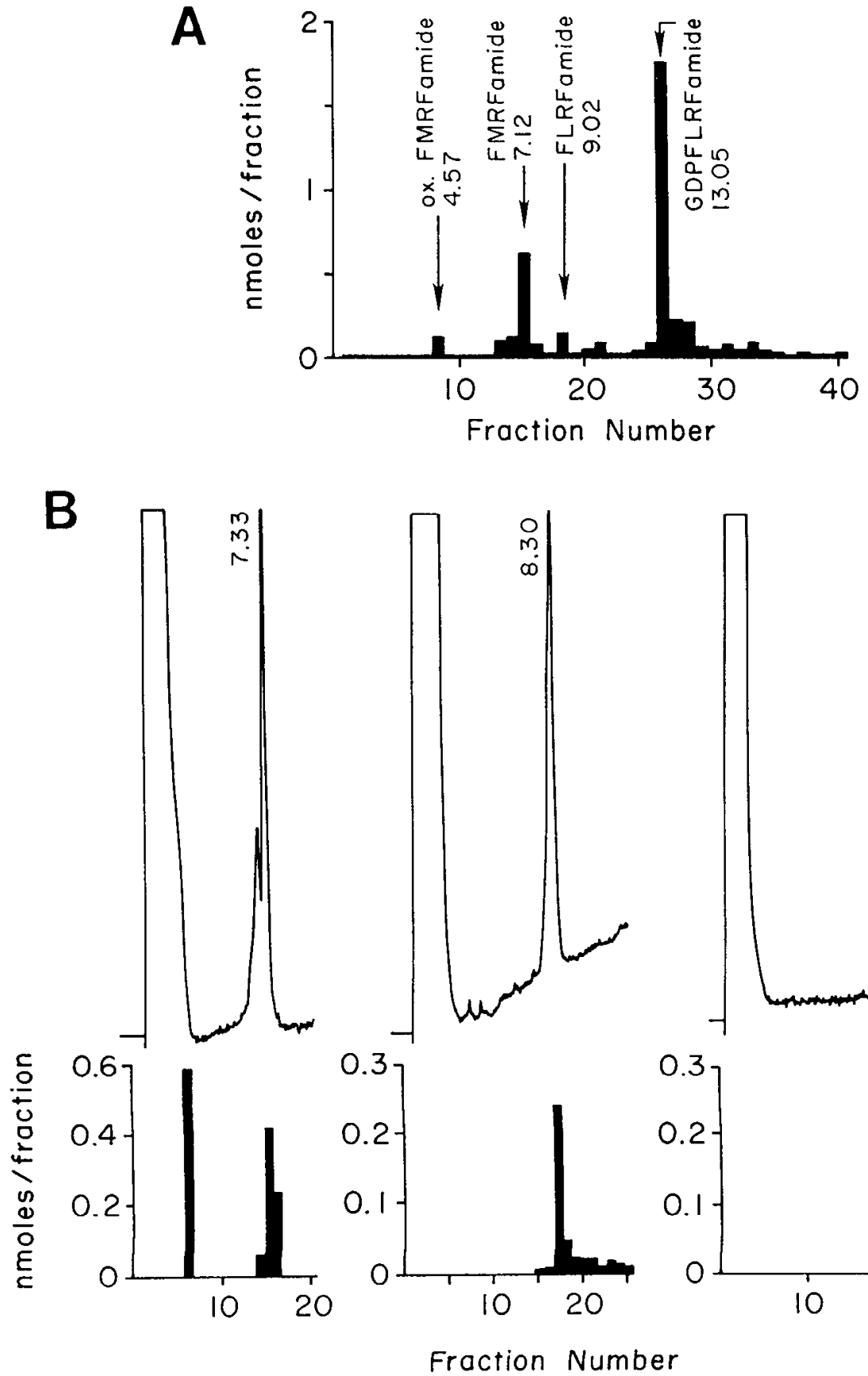
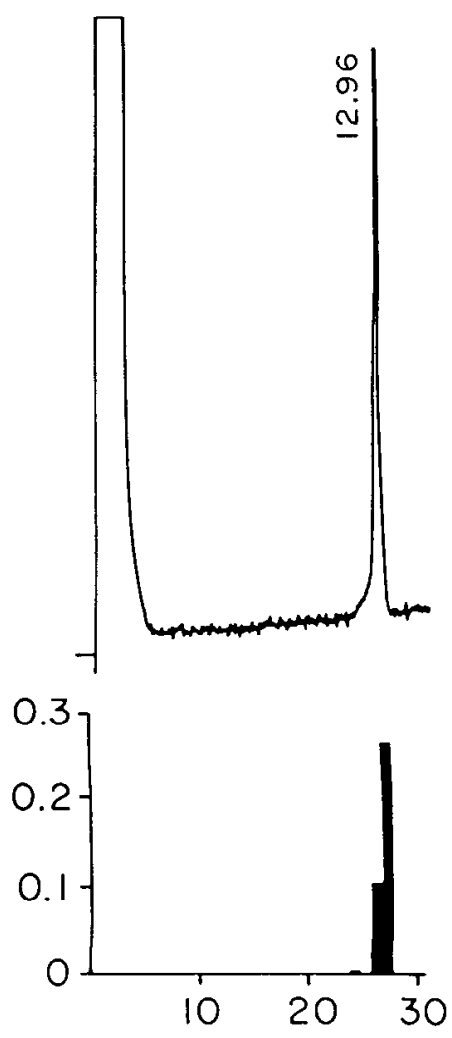

\section{FMRFamide immunohistochemistry of the salivary gland}

Since FMRFamide can modulate the amplitude of gland EPSPs (Coates and Bulloch, 1985) and since FMRFamide-like peptides are present in Helisoma (above), our subscquent studics were intended to place these observations in a physiological context. In order to test for the presence of FMRFamide-like fibers upon the salivary gland, we screened a polyclonal antiserum on both whole mounts and wax sections of preparations of the central ring ganglia, buccal ganglia, and attached salivary glands. This antiserum (in common with the one used in the above RIA analysis) does not distinguish between FMRFamide, FLRFamide, or the heptapeptides and therefore cannot be used to examine the respective location of the different peptides. The presence of many FMRFamide-immunoreactive (irFMRFamide) cell bodies both in the buccal ganglia and the central ring ganglia, as reported previously (Murphy et al., 1985), were again noted in this study. Additionally, however, the presence of a network of varicose irFMRFamide fibers was evident in both whole mounts and scctions of the salivary glands (Fig. 4). This network of fibers exhibited a distinct proximal-distal distribution, being profuse upon the distal half of each gland and more restricted proximally (Fig. 4, $B, C$ ). Most of the fibers ran either upon or close to the surface of the gland cells, and many appeared to be derived from a single irFMRFaxon that entered the gland via the salivary nerve (Fig. $4, A, B$ ). In some preparations it was possible to trace the irFMRFamide axon into the esophageal nerve trunk by which it entered the buccal ganglia. This axon ran unbranched through the buccal ganglia, exited via the ipsilateral cerebrobuccal connective, and subsequently entered the 


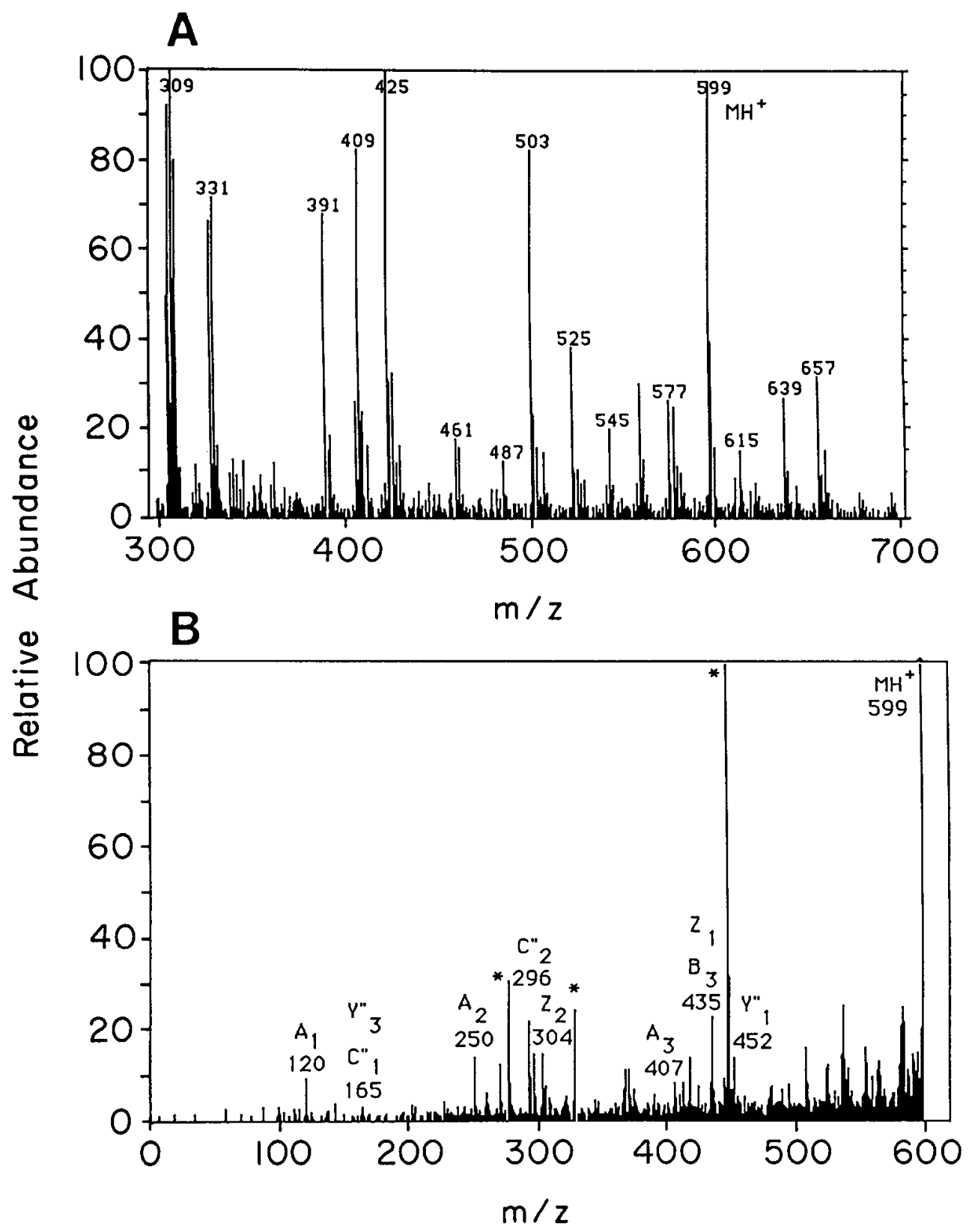

Figure 2. Mass spectrometry separation of FMRFamide. $A$, Normal (magnetic sector scan) positive-ion FAB mass spectrum for FMRFamide peptide. The prominent ion at $m / z 599$ corresponds to the protonated molecular ion. Other prominent ions in the spectrum are due to the sample matrix. $B$, Daughter-ion spectrum (B/E linked scan) for mass 599 . Sequence-related fragments for FMRFamide are indicated by mass number and assigned using the Roepstorff nomenclature for fragment ion series (Roepstorff and Fohlman, 1984.) Peaks known to be artifacts derived from the matrix are marked with an asterisk. The peak for the parent ion $(\mathrm{m} / z$ 599) is saturated, and intensities are scaled to the next most intense ion. cerebral ganglion. Despite examination of 20 preparations, because of the thickness and complexity of irFMRFamide fibers and somata in the central ring ganglia, the origin of this axon has yet to be determined.

Attempts were made to preabsorb the FMR Famide antiserum with either synthetic FMRFamide or a FMRFamide-thyroglobulin conjugate similar to that used to generate the antiserum. The peptide itself showed poor ability to block the staining; however, an almost complete block was obtained with the conjugate, virtually no fibers being evident in the salivary gland (Fig. 4D). As negative controls, thyroglobulin itself and a GABABSA conjugate were tested; neither showed any ability to block the staining.

\section{FMRFamide modulation of neuroglandular activity}

The peptide FMRFamide is known to reduce the amplitude of the gland EPSP evoked by neuron 4 (Coates and Bulloch, 1985). However, this previous study utilized high-magnesium, low- calcium salines to examine subthreshold modulation of the gland EPSP, whereas the modulation of gland action potentials in normal saline (i.e., under more physiological conditions) was not examined. In the present study we examined the modulation of neuroglandular activity during the PMA that is associated with feeding and is expressed spontaneously in isolated preparations (Kater, 1974; Murphy et al., 1985; Jones et al., 1987).

In order to maximize the significance of these experiments, we utilized all 3 of the endogenous FMRFamide peptides indicated by our preceding analysis. Each of these modulated the neuroglandular synapse; however, the actions of the tetrapeptides differed from those of the heptapeptide. Thus, application of either FMRFamide or FLRFamide at micromolar concentrations caused a strong, slow hyperpolarization of neuron 4 , suppression of its synaptic inputs and action potentials, and consequently eliminated driven action potentials in the salivary gland (Fig. 5A). Additionally, the tetrapeptides elicited a slow hyperpolarization of the gland cells, which was, however, small- 


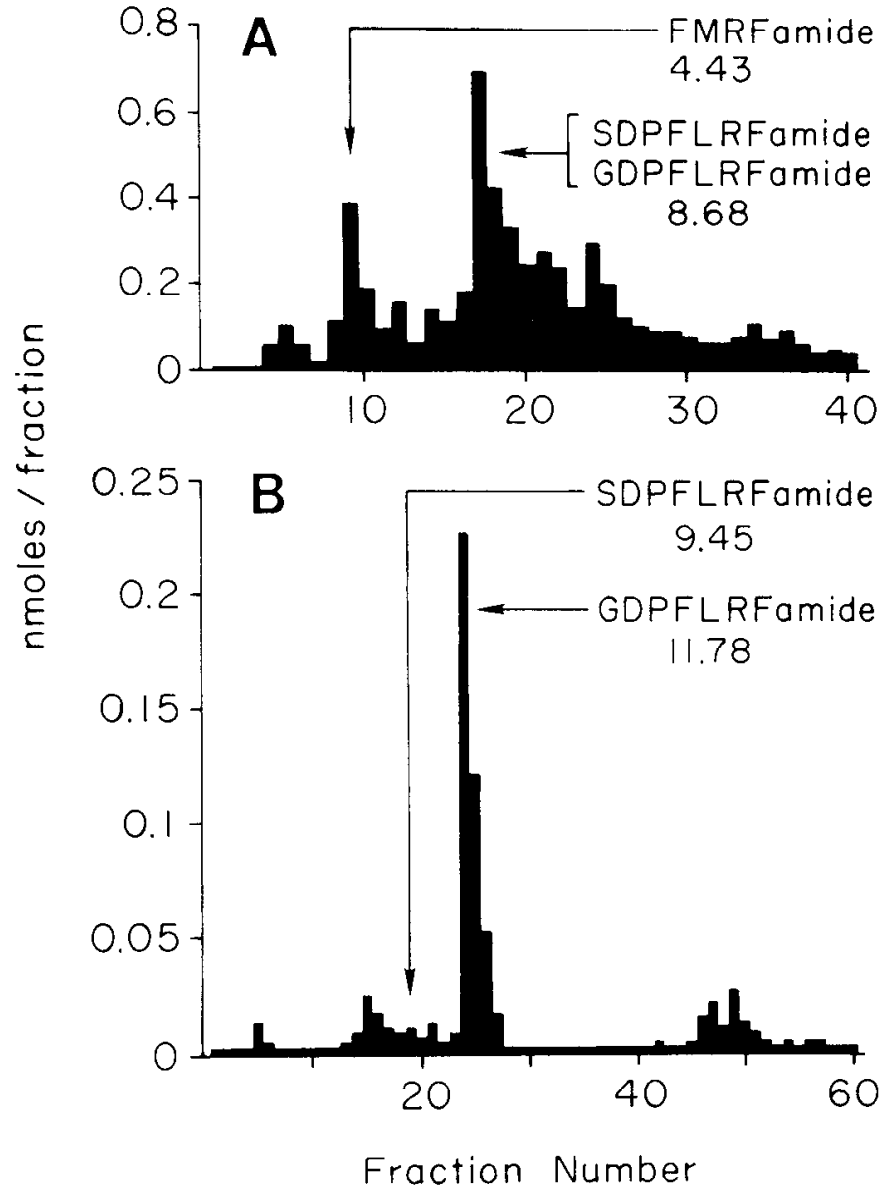

Figure 3. Immunoreactivity profiles of an HPLC fractionation of an acetone extract of dissected snail ganglia. $A$, Fractionation on an ACN/ TFA system similar to that used in Figure 1 but with a gradient from 0 to $32 \% \mathrm{ACN}$ in $0.1 \%$ TFA over $20 \mathrm{~min}$. $B$, Fractions $17-21$ (Fig. $3 A$; corresponding in elution time to the unresolved heptapeptides GDPFLRFamide and SDPFLRFamide) were combined, lyophilized, taken up in sodium caprylate buffer, and injected onto a NovaPak column eluted with a gradient of ACN from 10 to $25 \%$ in $3 \mathrm{~mm}$ sodium caprylate (pH 7.0) over $20 \mathrm{~min}$. Standard SDPFLRFamide and GDPFLRFamide were resolved as shown.

er in amplitude than that observed in neuron 4 (Fig. 5A). Application of GDPFLRFamide also eliminated gland action potentials but caused a stronger hyperpolarization of gland cells than the tetrapeptides. Thus, GDPFLRFamide at micromolar concentration caused a similar hypcrpolarization of neuron 4 to FMRFamide but elicited a large, rapidly developing hyperpolarization of the gland cells (Fig. $5 B$ ). The differences between the tetrapeptides and GDPFLRFamide are clearly illustrated by dose-response relationships that use maximum hyperpolarization as an index of peptide efficacy (Fig. 6). Despite differences of action, the threshold dose for all 3 peptides was $10^{-8} \mathrm{M}$.

The reduction of synaptic inputs to neuron 4 by the FMRFam- ide peptides suggested a decrease of input impedance. This possibility was tested by measurement of the input impedance of neuron 4 during iontophoresis of FMRFamide in high- $\mathrm{Mg}^{2+}$ low- $\mathrm{Ca}^{2+}$ saline (used to block the impedance fluctuations due to spontaneous synaptic inputs). This test showed that FMRFamide causes a substantial decrease of input impedance in neuron 4 (Fig. 7), i.e., an action similar to that on the salivary gland (Coates and Bulloch, 1985).

Although bath application of FMRFamide peptides produced significant results, we wished to test the consequences of local release of FMRFamide. We approached this by iontophoresis of this peptide either upon neuron 4 or directly on the salivary gland. FMRFamide application to the soma of neuron 4 caused effects resembling those observed during bath application. Thus, iontophoresis of FMRFamide caused a hyperpolarization of neuron 4 that reduced the amplitude of synaptic inputs and suppressed action potential activity in both neuron 4 and the gland (Fig. 8). The amplitude of the hyperpolarization and suppression of action potentials were dependent on the iontophoretic current, near or complete suppression of impulses being obtained with currents of $50-100 \mathrm{nA}$ in all trials $(n=26$ in 3 preparations).

Suppression of action potentials in gland cells could also be obtained by iontophoresis of FMRFamide upon a gland acinus. In this case, the iontophoretic electrode was placed over the same acinus in which the recording electrode had been inserted. FMRFamide is known to cause a decrease of input impedance in gland cells (Coates and Bulloch, 1985), and this was sufficient to shunt the EPSP below spike threshold during FMRFamide application (Fig. 9). Successful reduction of gland EPSPs below spike threshold was obtained in $84 \%$ of trials $(n=44$ in 4 preparations) using iontophoretic currents of 50-150 nA.

In principle, the reduction of gland EPSPs could be partly the result of reduced release of transmitter, as well as a postsynaptic conductance increase. We examined the postsynaptic locus using direct activation of the salivary gland by iontophoresis of the putative transmitter of neuron 4, i.e., ACh (Bahls, 1987). Two steps were taken to remove presynaptic input from the gland. First, the gland was isolated from the buccal ganglia, and second, the preparation was perfused with a high- $\mathrm{Mg}^{2+}$, low$\mathrm{Ca}^{2+}$ saline to block the spontaneous synaptic release that still occurs in the isolated gland. ACh iontophoresis readily evokes depolarizations when applied to the salivary gland under these conditions. Simultaneous iontophoresis of FMRFamide (50$150 \mathrm{nA}$ ) from an adjacent electrode caused a reduction in the amplitude of these depolarizations (Fig. 10). The degree of reduction of the ACh-induced depolarizations was substantial (51 $\pm 3 \%, n=19$ trials in 4 preparations), confirming that the postsynaptic membrane is a major locus of action for FMRFamide at neuroglandular junctions.

\section{Discussion}

This study is one of a series of investigations designed to examine the modulation of the neuronal circuitry underlying feed-

Figure 4. FMRFamide immunohistochemistry of the Helisoma salivary gland. A. Low-magnification view of the Helisoma buccal ganglia (upper) and proximal segments of the paired salivary glands (lower). A single irFMRFamide axon can be seen entering each salivary gland via the salivary nerve (triangle). These axons are not derived from the irFMRFamide somata in the buccal ganglia, but rather descend from the ring ganglia via the cerebrobuccal connectives $(6.3 \times$ objective). $B$, Higher-magnification view of the midsection of the left-hand salivary gland shown in $A$. This demonstrates the region at which the distal half of each gland becomes densely innervated by a varicose network of irFMRFamide fibers. The axon 

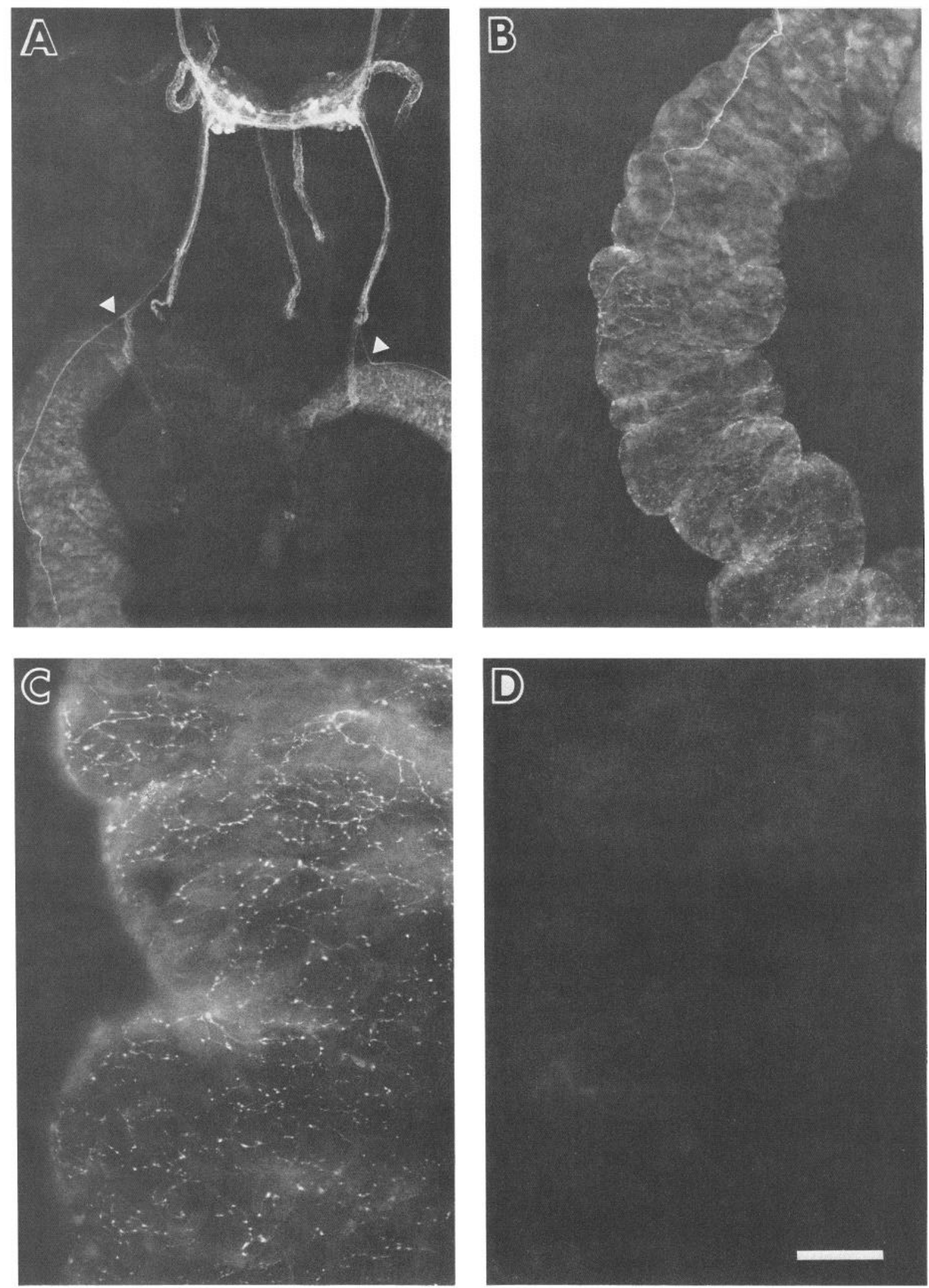

from which these fibers are largely derived is clearly visible in the upper half of the figure (10× objective). $C$, High-magnification view of the distal portion of the left-hand gland shown in $A$. The objective was focused on the top surface of the salivary gland, demonstrating the dense innervation by irFMRFamide fibers of this region $(25 \times$ objective). $D$, High-magnification view of the distal portion of a salivary gland in a preparation treated with the antiserum preabsorbed with FMRFamide-thyroglobulin. The plane of focus was the top surface of the gland, i.e., similar to that in $C$. No irFMRFamide fibers are evident (25× objective). Calibration bar: $A, 200 \mu \mathrm{m} ; B, 125 \mu \mathrm{m} ; C$ and $D, 50 \mu \mathrm{m}$. 

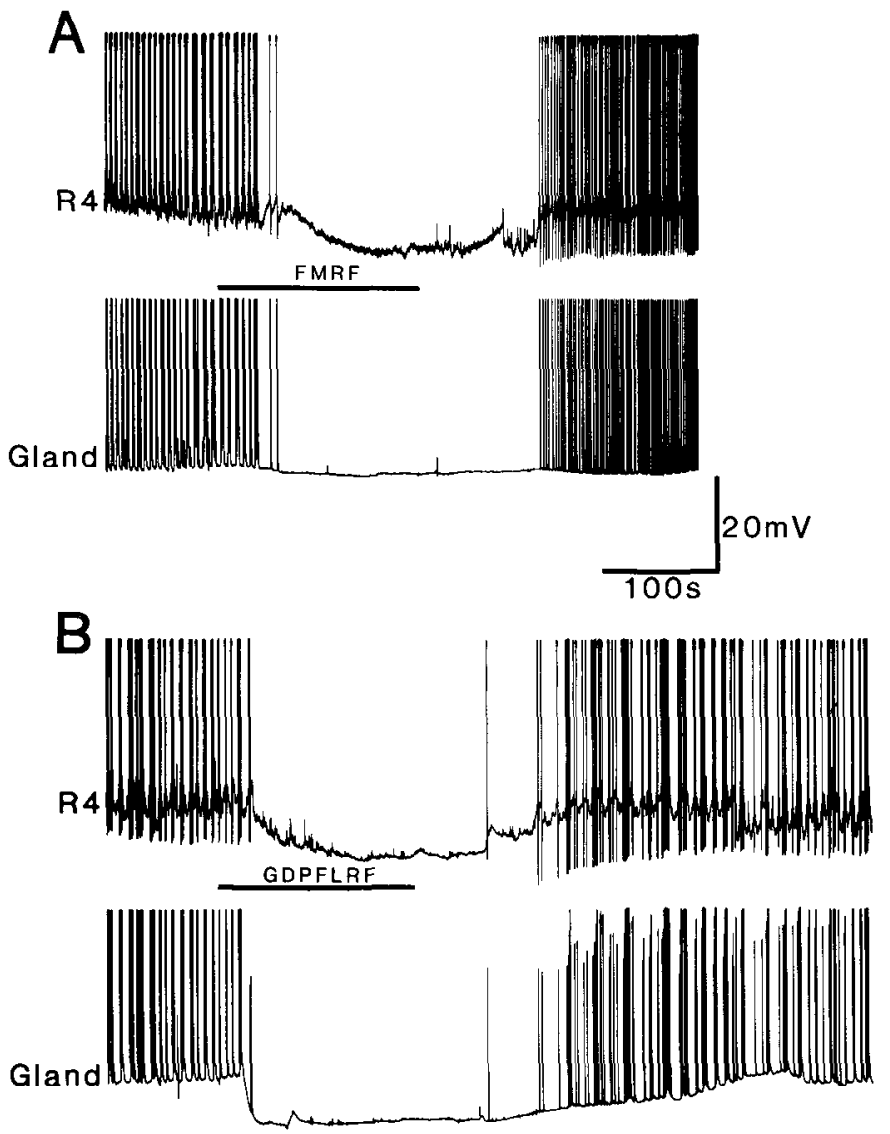

Figure 5. Modulation of neuron 4-gland activity by FMRFamide and GDPFLRFamide. These records represent simultaneous recordings from a neuron 4 and a gland cell during spontaneously expressed PMA. Bath application of the peptide at micromolar concentration caused a hyperpolarization of both neuron 4 and the gland cell in each preparation. The hyperpolarization of neuron 4 was similar in both cases; however, the heptapeptide induced a larger and faster hyperpolarization of gland cells than the tetrapeptide. Dose-response relationships for the 2 peptides are shown in Figure 6.

ing in Helisoma. We provide here the first definitive identification of a family of neuroactive peptides in Helisoma, i.e., FMRFamide and 2 of its analogs. In addition to separation of these peptides by HPLC/RIA analysis, the presence of the true peptides was confirmed both by the presence of intense molecular ions observed at the expected $\mathrm{m} / \mathrm{z}$ positions, as well as predicted sequence ions in linked scan mass spectra. These results demonstrate the utility of FAB mass spectrometry in the analysis of peptides (Lee, 1986).

Three FMRFamide-related peptides-FMRFamide, FLRFamide, and GDPFLRFamide - are present in Helisoma. Of these, FMRFamide has previously been reported from a number of molluscan species, and although FLRFamide has been definitively reported in only a few species, it appears to be a ubiquitous, although quantitatively minor, molluscan peptide (D. A. Price, unpublished observations). Heptapeptides of the XDPFLRFamide ( $\mathrm{X}=\mathrm{Gly}$, Ser, Asn, or pGlu) series are present only in pulmonates (reviewed by Price et al., 1987), one member of this group being present in Helisoma, although all other species examined have 2 or more. It is not known whether a single heptapeptide is characteristic of the whole genus Helisoma, only the species ancestral to the laboratory strain, or even solely to this inbred laboratory strain. It is possible that the multiple

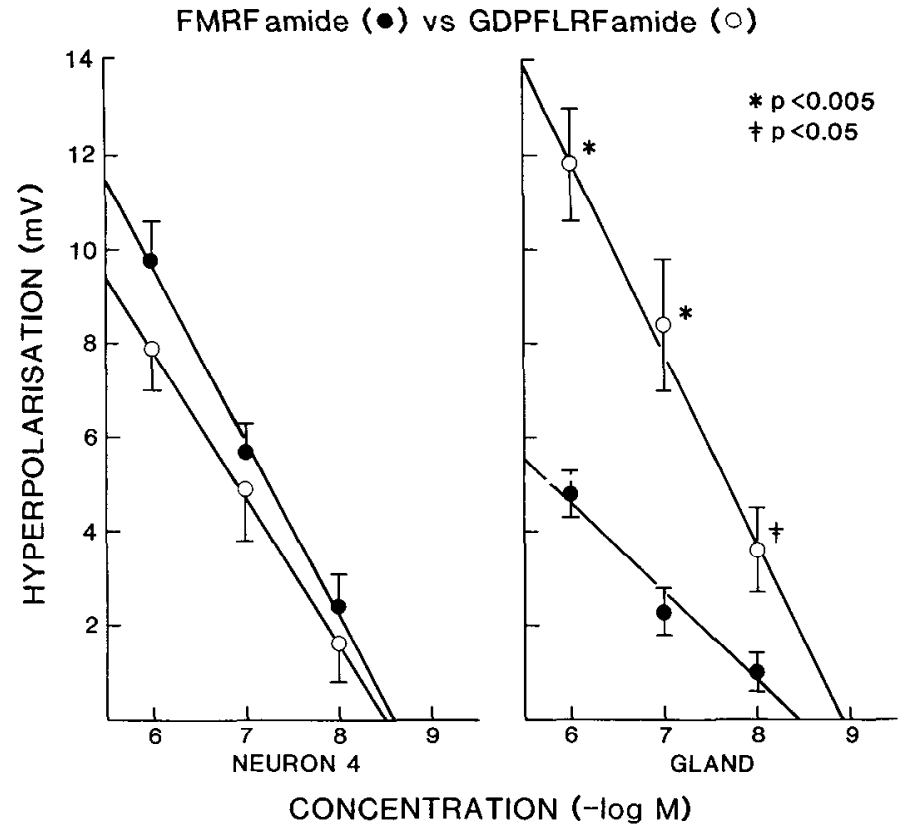

Figure 6. Dose-response relationships for FMRFamide and GDPFLRFamide. The degree of hyperpolarization of cells at different concentrations of each peptide is used as an index of peptide efficacy. The greater efficacy of GDPFLRFamide on gland cells is clearly demonstrated; additionally, FMRFamide caused a larger hyperpolarization of neuron 4 than gland cells $\left(P<0.001\right.$ at $10^{-6}$ and $10^{-7} \mathrm{M}$; not significant at $10^{-8} \mathrm{M}$ ). Each data point represents the mean response obtained in $7-10$ trials in $4-5$ preparations.

heptapeptides seen in other species reflect allelic variation that has been lost in this strain, but an answer to this question requires sequencing of the heptapeptide precursor gene. Nevertheless, the heptapeptide peak accounts for the greater part of the immunoreactivity in Helisoma, as it does in other pulmonate species. No difference in the effects of SDPFLRFamide versus GDPFLRFamide or of FLRFamide versus FMRFamide (data not shown) were observed in this study, but differences were obvious between the tetrapeptides and heptapeptides (discussed below). Thus, the division of FMRFamide-related peptides into tetra- and heptapeptides may be physiologically relevant.

The results of the current study and of a previous one (Coates and Bulloch, 1985) provide evidence that FMRFamide peptides can modulate neuroglandular activity. Such peptides can act both on the effector neuron and the postsynaptic target. Thus, these peptides elicit a conductance increasc of the salivary gland

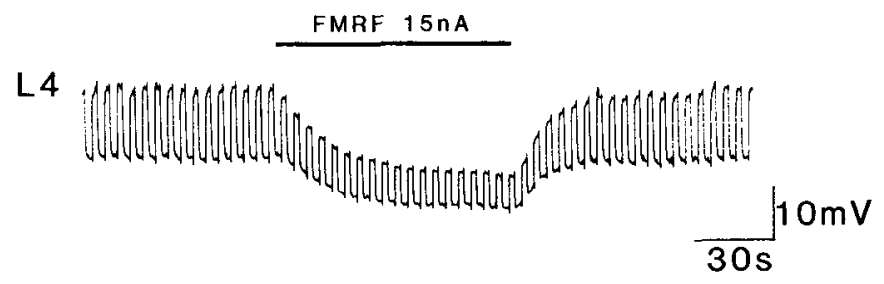

Figure 7. Demonstration of the conductance change in neuron 4 caused by FMRFamide. FMRFamide was iontophoresed onto the cell body of neuron L4 during the period indicated. The input impedance of the neuron was monitored by passage of constant-current hyperpolarizing pulses $(0.2 \mathrm{nA}$ at $0.2 \mathrm{~Hz})$. In this example, FMRFamide caused a $46 \%$ loss of input impedance. Preparation bathed in high- $\mathrm{Mg}^{2+}$, low-Ca ${ }^{2+}$ saline. 


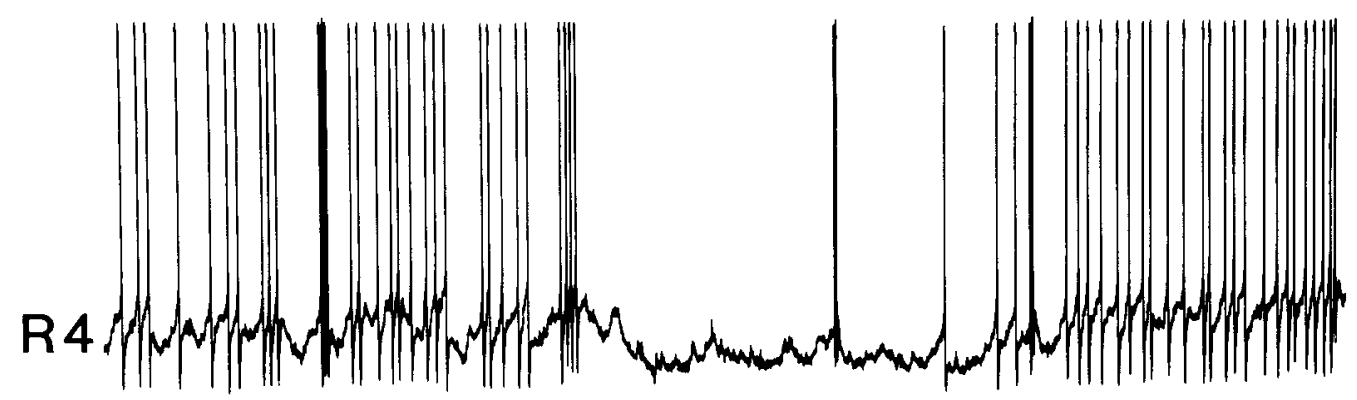

FMRF $100 \mathrm{nA}$

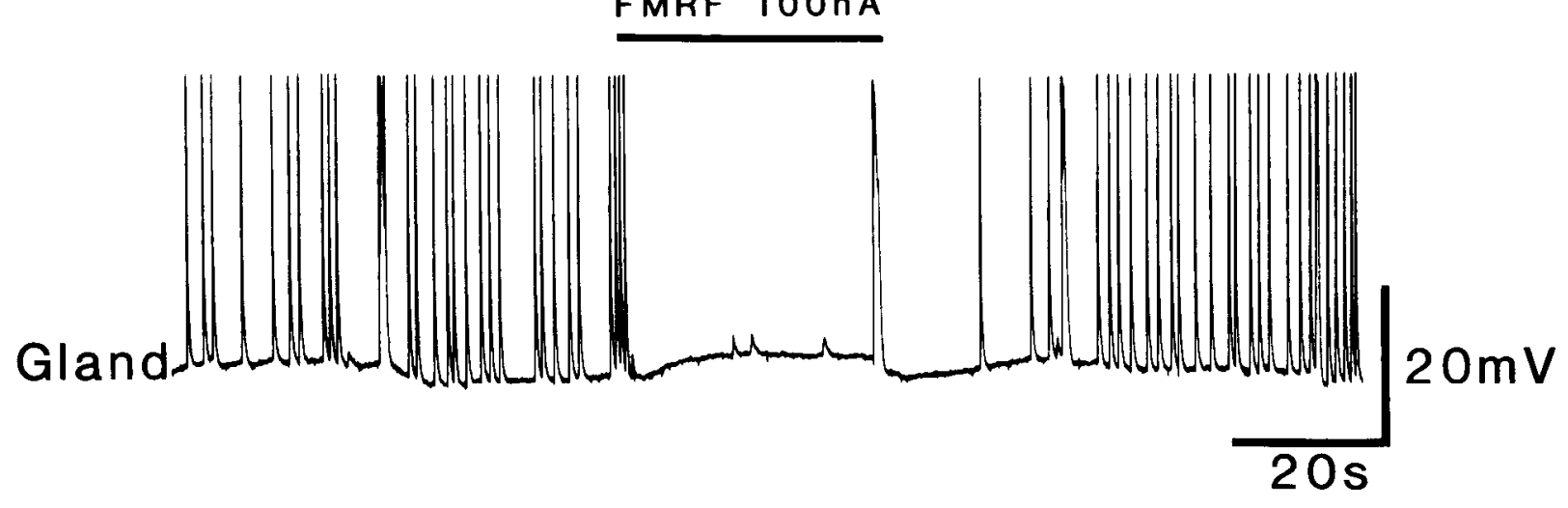

Figure 8. FMRFamide iontophoresis on neuron 4 during spontaneous PMA. FMRFamide application hyperpolarized neuron 4 and suppressed action potential activity, subsequently eliminating driven action potentials in the gland cell. Normal activity resumed shortly after termination of the iontophoresis.

cells that can reduce the normally suprathreshold EPSPs from neuron 4 to below threshold. Our peptide analysis indicated the presence of both GDPFLRFamide and a smaller amount of FMRFamide in the salivary glands themselves. Interestingly, the heptapeptide caused a larger and faster hyperpolarization of gland cells than either FMRFamide or FLRFamide. In terms of actions on the effector neuron, the FMRFamide peptides caused a hyperpolarization of neuron 4 due to a conductance increase (Fig. 7). The latter conductance change shunted ongoing synaptic activity during PMA and suppressed spiking activity in neuron 4 , thus removing the cxcitatory drive to the salivary glands (Fig. 8). In this study we applied FMRFamide by iontophoresis to the cell body of neuron 4. It is not known whether the FMRFamide receptors are located upon the cell body or upon closely located synaptic regions in the neuropil. In either case, FMRFamide activation of receptors upon neuron 4 can prevent activation of the salivary glands. It is important to note that FMRFamide can also act on premotoneurons in the buccal ganglia to suppress the rhythmic synaptic drive to effector neurons during PMA (Murphy et al., 1985). Nevertheless, its action on neuron 4 itself is sufficient to suppress action potentials in the salivary glands.

Although the FMRFamide peptides have a pronounced effect on the activity of neuron 4 when applied near the cell body, it is unknown whether these agents can exert a presynaptic action at the terminals of neuron 4. Although the molluscan cell body is often used as a "model" of the terminals, it is imperative to test for presynaptic actions directly. In the present case, experiments could utilize iontophoresis of FMRFamide near the terminals of neuron 4 during direct stimulation of its cell body. Conceivably, as an alternative approach, FMRFamide could be released by stimulation of the cerebrobuccal connective. It will be necessary, however, to distinguish a possible presynaptic effect from the direct action of FMRFamide on the gland cells. To this end, the gland EPSP could be reduced below threshold (by changing the calcium/magnesium ratio - see Coates and Bulloch, 1985) and determining whether the change in postsynaptic potential is more than that predicted from its direct effect on gland cells. Although there will be some difficulty in ascertaining that the iontophoretic electrode is in close opposition to a neuron 4 terminal, this kind of approach will be essential to examine presynaptic modulation in this system.

Identification of the ionic currents activated by the 3 FMRFamide peptides of Helisoma was beyond the resolution of the present study. That the tetra- and heptapeptide analogs of the FMRFamide peptides can activate different currents, however, has been demonstrated on identified neurons of the gastropod mollusc Helix (Cottrell and Davies, 1987). These authors showed that 3 tetrapeptide amides (FMRFamide, FLRFamide, and FIRFamide) behave similarly but that their actions differ from 2 heptapeptide amides (YGGFMRFamide and $p Q D P F L R F a m i d e)$. Interestingly, whereas all of these peptides could activate increases of $\mathrm{K}^{+}$conductance, only the tetrapeptides could activate an increase of $\mathrm{Na}^{+}$conductance.

The 3 peptides that have received the most attention to date with respect to feeding in molluscs are the FMRFamide family (Greenberg and Price, 1983; Murphy et al., 1985; Lloyd et al., 1987), the small cardioactive peptide family (SCP; Lloyd et al., 1984, 1985, 1987; Murphy et al., 1985; Murphy and Lukowiak, 1987), and egg-laying hormone (ELH; Stuart and Strumwasser, 1980; Cobbs and Pinsker, 1982a, b; Sossin et al., 1987). These studies reveal some common themes. Thus, for example, application of $\mathrm{SCP}_{\mathrm{B}}$, ELH, or 5-HT elicits synaptic barrages and rhythmic bursting in effector neurons of both Helisoma and Aplysia, whereas such activity is inhibited by FMRFamide (Granzow and Kater, 1977; Murphy et al., 1985; Sossin et al., 


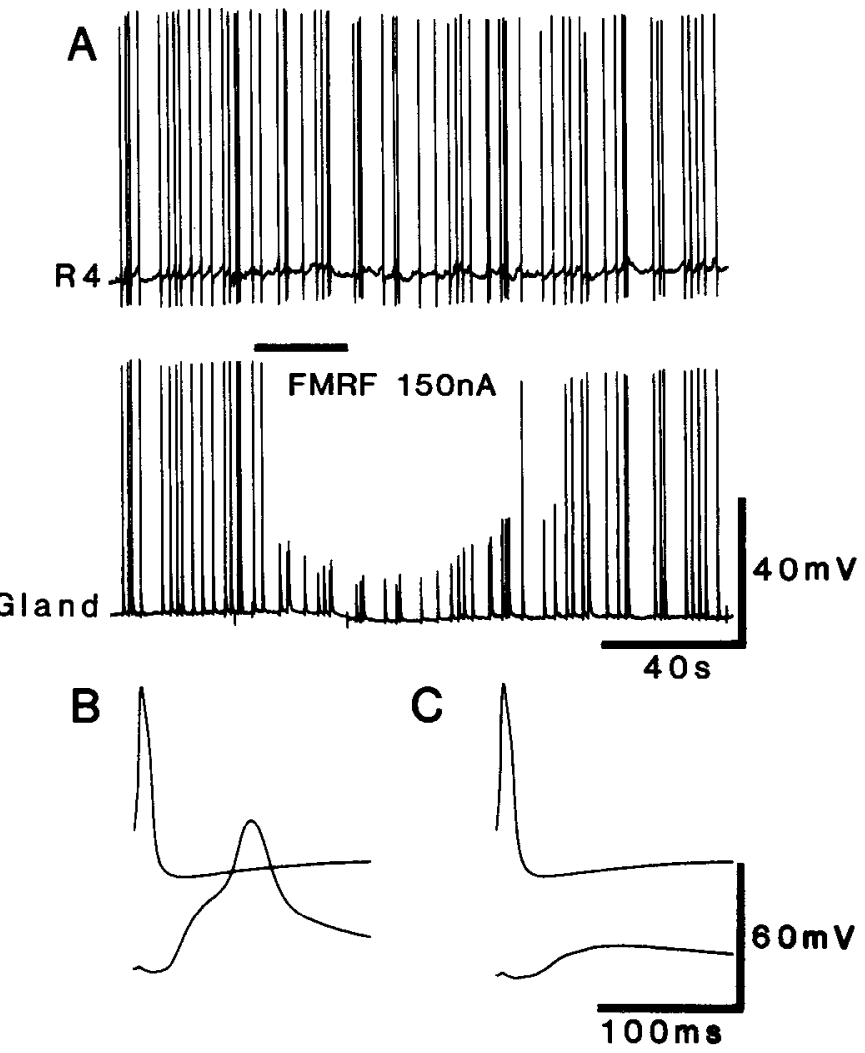

Figure 9. FMRFamide iontophoresis on a gland cell during spontaneous PMA. The conductance increase in the gland cells due to FMRFamide caused a hyperpolarization and reduced the EPSP below threshold. Examples of neuron 4 action potentials and the waveform elicited in the gland cell before and during FMRFamide iontophoresis are shown in $B$ and $C$, respectively.

1987; this study). It has been suggested that the specific pattern of motoneuron activity elicited by different neuroactive agents may reflect the diverse behavioral repertoire characteristic of feeding in molluscs (McClellan, 1982a, b; Sossin et al., 1987; Murphy and Lukowiak, 1987).

Several neurons in Helisoma that were identified as peptidergic by immunohistochemistry have also been characterized physiologically (Lukowiak and Murphy, 1987; Murphy and Lukowiak, 1987). It is also possible to demonstrate specific individual peptides in identified molluscan neurons. For example, a neuron in Helix is known to contain genuine FMRFamide

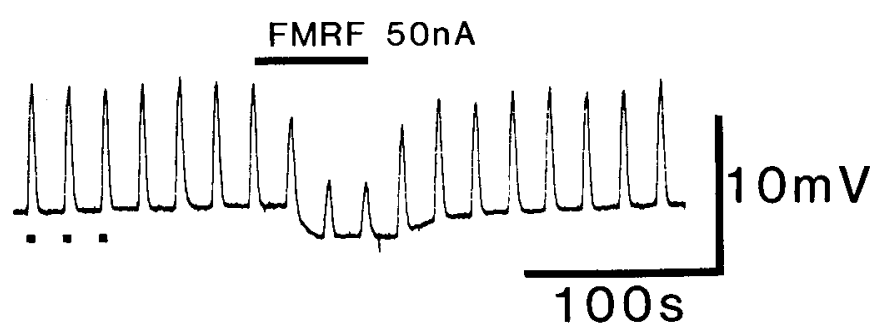

Figure 10. Reduction of ACh-induced depolarizations in gland cells by FMRFamide iontophoresis. The regularly occurring depolarizations of this gland cell were induced by iontophoresis of $\mathrm{ACh}(3 \mathrm{sec}$ pulses at $15 \mathrm{sec}$ intervals, $+10 \mathrm{nA}$ ejection current, $-3 \mathrm{nA}$ backing current e.g., at dots). Application of FMRFamide during the indicated period caused a hyperpolarization and a $60 \%$ reduction in amplitude of the depolarizations. Preparation bathed in high- $\mathrm{Mg}^{2+}, \mathrm{low}-\mathrm{Ca}^{2+}$ saline. and to innervate a tentacle muscle (Cottrell et al., 1983). In the case of Aplysia, several of the peptidergic neurons revealed by immunocytochemistry are large enough to permit analysis of the peptides synthesized by individual cells. This method has made it possible to confirm that individual buccal neurons synthesize either FMRFamide, $\mathrm{SCP}_{\mathrm{A}}$, or $\mathrm{SCP}_{\mathrm{B}}$, or all 3 peptides (Lloyd et al., 1987). Taken together, these studies demonstrate the utility of the molluscan nervous system, in studies ranging from behavior to the biochemistry of single identified neurons, for understanding the regulation of complex behaviors.

\section{References}

Bahls, F. (1987) Acetylcholine-induced responses in the salivary gland cells of Helisoma trivolvis. Neurobiology 7: 35-47.

Bahls, F., S. B. Kater, and R. W. Joyner (1979) Neuronal mechanisms for bilateral coordination of salivary gland activity in Helisoma. J. Neurobiol. 11: 365-379.

Benjamin, P. R., C. J. H. Elliott, and G. P. Ferguson (1985) Neural network analysis in snail brain. In Model Neural Networks and Behavior, A. I. Selverston, ed., pp. 87-108, Plenum, New York.

Bloom, F. E. (1983) The endorphins: A growing family of pharmacologically pertinent peptides. Annu. Rev. Pharmacol. Toxicol. 23: 151-170.

Bulloch, A. G. M. (1987) Somatostatin enhances neurite outgrowth and electrical coupling of regenerating neurons in Helisoma. Brain Res. 412: 6-17.

Chronwall, B. M., J. A. Olschowka, and T. L. O'Donohue (1984) Histochemical localization of FMRFamide-like immunoreactivity in the rat brain. Peptides 5: 569-584.

Coates, C. J., and A. G. M. Bulloch (1985) Synaptic plasticity in the molluscan peripheral nervous system: Physiology and role for peptides. J. Neurosci. 5: 2677-2684.

Cobbs, J. S., and H. M. Pinsker (1982a) Role of bag cells in egg deposition of Aplysia brasiliana. I. Comparison of normal and elicited behavior. J. Comp. Physiol. 147: 523-535.

Cobbs, J. S., and H. M. Pinsker (1982b) Role of bag cells in egg deposition of Aplysia brasiliana. II. Contribution of egg movement to elicited behaviors. J. Comp. Physiol. 147: 537-546.

Cottrell, G. A., and N. W. Davies (1987) Multiple receptor sites for a molluscan peptide (FMRFamide) and related peptides of Helix. J. Physiol. (Lond.) 382: 51-68.

Cottrell, G. A., L. P. C. Schot, and G. J. Dockray (1983) Identification and probable role of a single neurone containing the neuropeptide Helix FMRFamide. Nature 304: 638-640.

Dixon, W. J., and F. J. Massey Jr. (1969) Introduction to Statistical Analysis, 3rd ed., McGraw-Hill, New York.

Edvinsson, L. (1985) Functional role of perivascular peptides in the control of cerebral circulation. TINS 8: 126-131.

Getting, P. A. 1985) Neural control of behavior in gastropods. In The Mollusca, Vol. 8: Neurobiology and Behavior, Part 1, A. O. D. Willows, ed., pp. 269-334, Academic, Orlando, FL.

Granzow, B., and S. B. Kater (1977) Identified higher-order neurons controlling the feeding motor program of Helisoma. Neuroscience 2: 1049-1063.

Greenberg, M. J., and D. A Price (1983) Invertebrate neuropeptides/ native and naturalized. Annu. Rev. Physiol. 45: 271-288.

Grimm-Jorgensen, Y. (1986) Peripheral endocrine functions of TRHand somatostatin-like molecules in freshwater gastropods. In Handbook of Comparative Opioid and Related Neuro-Peptide Mechanisms, G. B. Stefano and M. K. Leung, eds., pp. 173-188, CRC Press, Boca Raton, FL.

Ip, N. Y., C. K. Ho, and R. E. Zigmond (1982) Secretin and vasoactive intestinal peptide acutely increase tyrosine 3-monooxygenase in the rat superior cervical ganglion. Proc. Natl. Acad. Sci. USA 79: 75667569.

Iversen, L. L. (1984) The Ferrier Lecture 1983. Amino acids and peptides: Fast and slow chemical signals in the nervous system? Proc. R. Soc. London [Biol.] 221: 245-260.

Jones, P. G., S. J. Rosser, and A. G. M. Bulloch (1987) Glutamate suppression of feeding and the underlying output of effector neurons in Helisoma. Brain Res. 437: 56-68.

Kaneko, C. R. S., M. Merickel, and S. B. Kater (1978) Centrally programmed feeding in Helisoma: Identification and characteristics 
of an electrically coupled premotor neuron network. Brain Res. 146 $1-21$.

Kater, S. B. (1974) Feeding in Helisoma trivolvis: The morphological and physiological bascs of a fixed action pattcrn. Am. Zool. 14: 10171036 .

Kater, S. B., and C. R. S. Kaneko (1972) An endogenously bursting neuron in the gastropod mollusc, Helisoma trivolvis. J. Comp. Physiol. 79: $1-14$.

Kater, S. B., and C. H. F. Rowell (1973) Integration of sensory and centrally programmed components in generation of cyclical feeding activity of Helisoma trivolvis. J. Neurophysiol. 36: 142-155.

Kater, S. B., A. D. Murphy, and J. R. Rued (1978) Control of the salivary glands of Helisoma by identified neurones. J. Exp. Biol. 72 91-106.

Lee, T. D. (1986) Analysis of peptides and proteins by fast atom bombardment and secondary ion mass spectrometry. In Microcharacterization of Peptides and Proteins, J. E. Shively, ed., pp. 403-441, Humana, Clifton, NJ.

Lloyd, P. E., I. Kupfermann, and K. R. Weiss (1984) Evidence for parallel actions of a molluscan neuropeptide and serotonin in mediating arousal in Aplysia. Proc. Natl. Acad. Sci. USA 81: 2934-2937.

Lloyd, P. E., A. C. Mahon, I. Kupfermann, J. L. Cohen, R. H. Scheller, and K. R. Weiss (1985) Biochemical and immunocytological localization of molluscan small cardioactive peptides in the nervous system of Aplysia californica. J. Neurosci. 5: 1851-1861.

Lloyd, P. E., M. Frankfurt, P. Stevens, and I. Kupfermann (1987) Biochemical and immunocytological localization of the neuropeptides FMRFamide, $\mathrm{SCP}_{\mathrm{A}}, \mathrm{SCP}_{\mathrm{B}}$, to neurons involved in the regulation of feeding in Aplysia. J. Neurosci. 7: 1123-1132.

Lukowiak, K., and A. D. Murphy (1987) Molluscan model systems for the study of neuropeptides. In Neuromethods 6, Peptides, A. A. Boulton, C. B. Baker, and Q. J. Pittman, cds., pp. 439-476, Humana, Clifton, NJ.

McClellan, A. D. (1982a) Movements and motor patterns of the buccal mass of Pleurobranchaea during feeding, regurgitation and rejection. J. Exp. Biol. 98: 195-211.

McClellan, A. D. (1982b) Re-examination of presumed feeding motor activity in the isolated nervous system of Pleurobranchaea. J. Exp. Biol. 98: 213-228.

Mclafferty, F. W., ed. (1983) Tandem Mass Spectrometry, Wiley, New York.

Morris, H. R., M. Panico, A. Karplus, P. E. Lloyd, and B. Riniker (1982) Identification by FAB-MS of the structure of a new cardioactive peptide from Aplysia. Nature 300: 643-645.

Mudge, A. W., S. E. Leeman, and G. D. Fischbach (1979) Enkephalin inhibits release of substance $P$ from sensory neurons in culture and decreases action potential duration. Proc. Natl. Acad. Sci. USA 76 : 526-530.

Murphy, A. D., and K. Lukowiak (1987) Identified small cardioactive peptide $\mathrm{B}$ immunorcactive neurons in the buccal ganglia of Helisoma. In Neurobiology, Molluscan Models, H. H. Boer, W. P. M. Geraerts, and J. Joose, eds., pp. 124-126 (Mon. Kon. Ned. Akad. Wetensch.), North-Holland, Amsterdam.

Murphy, A. D., K. Lukowiak, and W. K. Stell (1985) Peptidergic modulation of patterned motor activity in identified neurons of $\mathrm{Heli}$ soma. Proc. Natl. Acad. Sci. USA 82: 7140-7144.

Nilsson, J., A. M. von Euler, and C. J. Dalsgaard (1985) Stimulation of connective tissue cell growth by substance $P$ and substance $K$. Nature 315: 61-63.

North, R. A., and J. T. Williams (1983) Opiate activation of potassium conductance inhibits calcium action potentials in rat locus coeruleus neurones. Br. J. Pharmacol. 80: 225-228.

O'Donohue, T. L., J. F. Bishop, B. M. Chronwall, J. Groome, and W. H. Watson III (1984) Characterization and distribution of FMRFamide immunoreactivity in the rat central nervous system. Peptides 5: 563-568.

Otsuka, M., S. Konishi, M. Yanagisawa, M. Tsumoo, and H. Akagi (1982) Role of substance $P$ as a sensory transmitter in spinal cord and sympathetic ganglia. In Substance $P$ in the Nervous System, R. Porter and M. O'Connor, eds., pp. 13-30, Pitman, London.

Pittman, Q. J. (1980) Peptide modulation of neuronal electrical responses. In Advances in Physiological Sciences, Vol. 14: Endocrinology, Neuroendocrinology, Neuropeptides-II, E. Stark, G. B. Makara, B. Halaz, and G. Rappay, eds., pp. 231-241, Pergamon, Budapest.

Price, D. A., N. W. Davies, K. E. Doble, and M. J. Greenberg (1987) The variety and distribution of the FMRFamide-related peptides in molluscs. Zool. Sci. 4: 395-410.

Roepstorff, P., and J. Fohlman (1984) Proposal for a common nomenclature for sequence ions in mass spectra of peptides. Biomed. Mass Spectrum 11: 601-602.

Said, S. I. (1980) Peptides common to the nervous system and the gastrointestinal tract. In Frontiers in Neuroendocrinology, Vol. 6, W. F. Ganong and L. Martini, eds., pp. 293-331, Raven, New York.

Sossin, W. S., M. D. Kirk, and R. H. Scheller (1987) Peptidergic modulation of neuronal circuitry controlling feeding in Aplysia. J. Neurosci. 7: 671-681.

Stuart, D. K., and F. Strumwasser (1980) Neuronal sites of action of a neurosecretory peptide, egg-laying hormone, in Aplysia californica. J. Neurophysiol. 43: 499-519.

Trimble, D. L., and D. L. Barker (1984) Activation by dopamine of patterned motor output from the buccal ganglia of Helisoma trivolvis. J. Ncurobiol. 15: $37-48$. 